\title{
Climatic signals in earlywood, latewood and total ring width of Corsican pine from western France
}

\author{
François Lebourgeois \\ Laboratoire Écosystèmes Forestiers et Dynamique du Paysage, Engref, 14 rue Girardet, 54042 Nancy Cedex, France
}

(Received 19 March 1999; accepted 15 November 1999)

\begin{abstract}
The influence of climatic factors on the growth of Corsican pine, growing at low elevation on acidic well-drained soils in western France, was evaluated by comparing annual earlywood, latewood and total ring indices with monthly temperature and precipitation data collected at Angers over the period 1922-1991. Latewood formation appeared to be more sensitive to climate than earlywood formation. Pointer years analysis and climatic models showed that summer drought was a major limiting-growth factor in the studied area. Extreme growth reductions specially highlighted the effects of low precipitation whereas response functions clearly underlined the importance of temperature. The climatic models accounted for $46 \%, 37 \%$ and $42 \%$ of the variability of total ring, earlywood and latewood indices, and suggested that the period of earlywood formation occurred mainly in early spring (May) whereas the growth of the latewood band was maximum in summer (July). Winter photosynthesis and the advance in the timing of the resumption of cambial activity were possible causes of the positive winter temperature correlation with earlywood. A cool and wet spring was also beneficial to growth as it affected the water balance of the trees at the beginning of the growing season. Prior October weather conditions also influenced growth, suggesting a preconditioning of the current year's growth by climate during the previous year. The regional climatic data revealed: no change in precipitation and thermal amplitude between 1950-1997; a significant $(\alpha=$ 0.01 ) increase in mean annual temperature of $1.1^{\circ} \mathrm{C}$, mean annual minimum temperature $\left(1.5^{\circ} \mathrm{C}\right)$, mean summer (July-August) temperature $\left(2.2^{\circ} \mathrm{C}\right)$ and minimum summer temperature $\left(2.3^{\circ} \mathrm{C}\right)$. By increasing summer water stress, a steady rise may induce growth decrease and probably forest decline in the next years. These results should be taken into account when predicting possible responses of Corsican pine plantations to global change
\end{abstract}

Pinus nigra / climate / global change / pointer years / earlywood / latewood / ring width / Corsican pine

Résumé - Analyse dendroclimatique du pin laricio de Corse dans l'ouest de la France. L'effet du climat sur la croissance de peuplements de pin laricio de Corse poussant à faible altitude sur des sols acides et bien drainés dans l'ouest de la France a été évalué en comparant la croissance annuelle du bois initial, du bois final et du cerne complet avec les données mensuelles de température et de précipitation collectées à Angers sur la période 1922-1991. La formation du bois final est apparue plus sensible au climat que celle du bois initial. L'analyse des années caractéristiques et des modèles climatiques a montré que la sécheresse estivale jouait un rôle majeur dans les variations inter-annuelles de croissance. Les réductions extrêmes de croissance sont liées aux faibles précipitations tandis que les fonctions de réponse soulignent le rôle de la température. Les modèles climatiques expliquent entre 37 et $46 \%$ de la variabilité inter-annuelle de la croissance selon le compartiment considéré, et suggèrent que le bois initial est élaboré au début du printemps (mai) et que la formation du bois final est maximale en été (juillet). La photosynthèse hivernale et la réactivation précoce du cambium pourraient expliquer l'effet positif des températures hivernales sur la formation du bois initial. En début de saison, la croissance est favorisée par un printemps frais et humide. L'influence des conditions du mois d'octobre de l'année qui précède la mise en place du cerne suggère un arrière-effet des conditions automnales sur la croissance annuelle. L'analyse des données climatiques n'a révélé aucune dérive de l'amplitude thermique et des précipitations. En revanche, les températures minimale et moyenne annuelles ont augmenté significativement $(\alpha<0.01)$ de $1,5^{\circ} \mathrm{C}$ et $1,1^{\circ} \mathrm{C}$ sur la période $1950-1997$. Pour la période estivale (juilletaoût), les augmentations sont respectivement de $2,3^{\circ} \mathrm{C}$ et $2,2^{\circ} \mathrm{C}$. En augmentant la sécheresse estivale, un réchauffement continu pourrait entraîner dans les prochaines années de fortes réductions de croissance voire un dépérissement forestier.

Pinus nigra / climat / changement climatique / années caractéristiques / bois initial / bois final / largeur de cerne / pin laricio de Corse

* Correspondence and reprints

Tel. 03833968 74; Fax.0383 3022 54; e-mail: lebourgeois@engref.fr 


\section{INTRODUCTION}

The drought years observed in several French regions in the 1970s and 1980s have focused attention on the effects of climatic variability upon the growth and the health of forests $[3,25]$. A recent dendroecological study carried out on Corsican pine stands (Pinus nigra ssp. laricio var. Corsicana) in western France showed a marked decrease in radial growth within the last 10 to 15 years that may be due to climatic effects [26]. Thus, to refine the tree-ring growth response to climate, an analysis of total ring, early- and latewood widths as separate variables of ring growth was undertaken. Such a study will allow to precise the time of the transition phase between both components and to partly assess the effect of climate on wood quality.

In recent years, evidence of 20th-century increase in mean annual temperature has prompted interest in the effects of climate warming on terrestrial ecosystems [5]. By increasing growing-season temperatures, such changes could have a dramatic effect on the pine environment. These effects may be exacerbated by less predictable changes in the amount and seasonality of precipitation. In this context, the climate-tree growth relationships could be used to assess the impact of a potential regional climate change on tree growth.

The objectives of this study were (1) to ascertain the relationships between climate and total ring, early- and latewood radial growth and (2) to evaluate possible trends in local climate parameters. The most prominent climatic factors affecting tree growth were identified (1) by distinguishing "pointer years", which correspond to abrupt changes in growth pattern and reveal the treegrowth response to extreme climatic events $[35,36]$ and (2) by establishing the mean relationships between tree ring and climate through simple correlations and response-function analysis $[10,11]$.

\section{MATERIALS AND METHODS}

\subsection{Study sites}

The correlation between tree chronologies and climate data depends on the distance between the tree sites and the weather station [23] and the correlation decreases with increasing separation [38]. Thus, among the 202 pure managed plots sampled in western France for a previous dendroecological study [26], the subsample of 13 plots localized within $20 \mathrm{~km}$ of the meteorological station was selected as study sites. The circular $600 \mathrm{~m}^{2}$ plots were sampled in plantations established after broad-leaf tree cuttings in forests. The site type was identified using the species composition of the ground vegetation and pedological criteria (soil description and chemical analysis) [28]. These plots presented low elevations $(25$ to $85 \mathrm{~m}$ ) and gently slopings (0 to 5\%). Soils were acidic, relatively poor with a dominant sandy soil texture [28]. The available water supply ranged from 42 to $99 \mathrm{~mm}$ and averaged $70 \mathrm{~mm}$. These well-drained soils suggested that trees may be susceptible to soil moisture stress during periods of low precipitation.

\subsection{Climatic records}

Monthly averaged temperatures $\left({ }^{\circ} \mathrm{C}\right)$ and monthly sums of precipitation $(\mathrm{mm})$ collected at Angers $\left(47^{\circ} 30^{\prime} \mathrm{N}, 00^{\circ} 35^{\prime} \mathrm{W}, 57 \mathrm{~m}\right)$ were used as explanatory variables. These data are representative of the regional climate (Atlantic climate) and are the longest climatic series available in the studied region. For the period 1961-1990, mean annual precipitation is $618 \mathrm{~mm}$ and the number of rainy days averages 161 (table I and figure 1). Annual temperature averages $11.5^{\circ} \mathrm{C}, 4.7^{\circ} \mathrm{C}$ and $19^{\circ} \mathrm{C}$ for mean, minimum and maximum temperature respectively. Snow-covered winters and late frosts in spring are rare. Average growing season (May to September) rainfall is $224 \mathrm{~mm}$ with $60 \%$ of rainless days and $30 \%$ of days with a maximum temperature above $25^{\circ} \mathrm{C}$. Thus,

Table I. Mean climatic conditions at Angers $\left(47^{\circ} 30^{\prime} \mathrm{N}, 00^{\circ} 35^{\prime} \mathrm{W}, 57 \mathrm{~m}\right)$. Means were calculated for the period 1961-1990. GS: growing season (May to September, 153 days).

\begin{tabular}{|c|c|c|c|c|c|c|c|c|c|c|c|c|c|c|}
\hline & Jan. & Feb. & Mar. & Apr. & May & June & Jul. & Aug. & Sept. & Oct. & Nov. & Dec. & Year & GS \\
\hline $\mathrm{Nb}$ of days with $P>0 \mathrm{~mm}$ & 16 & 14 & 15 & 14 & 15 & 11 & 10 & 11 & 11 & 13 & 16 & 15 & 161 & 58 \\
\hline$T \min \left({ }^{\circ} \mathrm{C}\right)$ & 1.8 & 2.2 & 3.5 & 5.4 & 8.6 & 11.5 & 13.4 & 13.1 & 11.2 & 8.2 & 4.4 & 2.4 & 7.1 & 11.6 \\
\hline$T \max \left({ }^{\circ} \mathrm{C}\right)$ & 7.6 & 9.0 & 11.9 & 14.8 & 18.3 & 22.0 & 24.6 & 24.2 & 21.8 & 17.0 & 11.2 & 8.2 & 15.9 & 22.2 \\
\hline $\mathrm{Nb}$ of days with $T \min \leq-5^{\circ} \mathrm{C}$ & 4 & 4 & 2 & 0 & 0 & 0 & 0 & 0 & 0 & 0 & 1 & 3 & 15 & 0 \\
\hline $\mathrm{Nb}$ of days with $T \max \geq 25^{\circ} \mathrm{C}$ & 0 & 0 & 0 & 2 & 3 & 8 & 14 & 12 & 6 & 2 & 0 & 0 & 47 & 43 \\
\hline
\end{tabular}




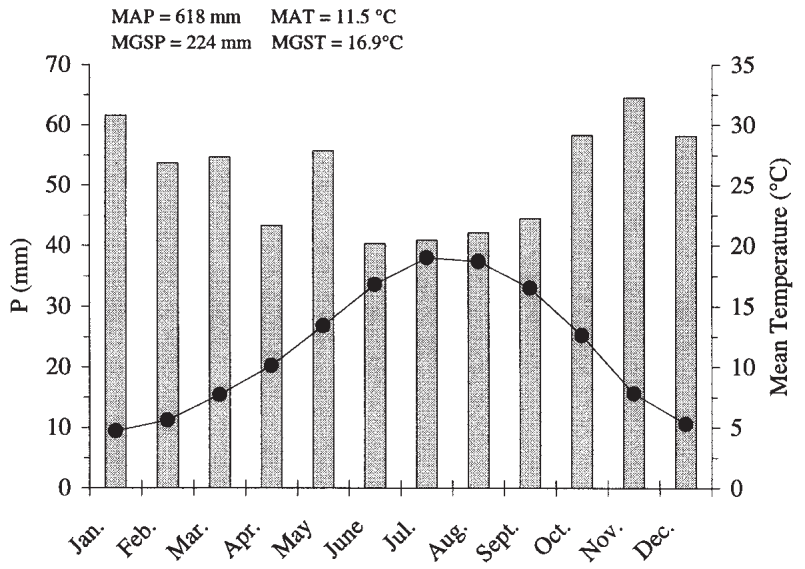

Figure 1. Climatic diagramm for Angers $\left(47^{\circ} 30^{\prime} \mathrm{N}, 00^{\circ} 35^{\prime} \mathrm{W}\right.$, $57 \mathrm{~m})$. Mean monthly temperature $\left({ }^{\circ} \mathrm{C}\right.$; line) and precipitation (mm; bars) were calculated for the period 1961-1990. MAP, MGSP, MAT and MGST = Mean Annual or Growing Season Precipitation and Temperature.

the studied area appears to have mild winters but a substantially dry and warm growth season relative to annual conditions.

To analyse possible trends in the local climatic data, the five monthly parameters available for the period 1950-1997 were used: maximum $\left(T_{\mathrm{x}}\right)$ and minimum $\left(T_{\mathrm{n}}\right)$ temperatures, thermal amplitude $\left(T_{\mathrm{x}}-T_{\mathrm{n}}\right)$, mean tempera- ture $\left(T_{\mathrm{m}}=1 / 2\left(T_{\mathrm{x}}+T_{\mathrm{n}}\right)\right)$ and precipitation $(P)$. From these monthly data, mean values were calculated for the year and the growing season. Climatic changes were investigated by observation of linear increasing trends over the period 1950-1997 and by calculation of the means at decacal scale.

For response function analysis (period 1922-1991), regressors were the monthly precipitations and the monthly mean temperatures for each biological year, i.e. from October to the previous growing season $(t-1)$ to September of the year in which the ring was formed (year $t$ ). These data were combined to form an array of 24 monthly regressors $[10,11]$. To eliminate any positive or negative trend effect induced by correlative trend in temperature or precipitation [2], climatic variables were standardized by linear functions.

\subsection{Measurements and statistical methods}

The 9 to 10 largest trees in diameter in each circular $600 \mathrm{~m}^{2}$ plot were bored to the pith at $1.30 \mathrm{~m}$ (one core per tree) and measured (total height $(H)$ and diameter at breast height outside bark (DBH)) (table II). The 128 dominant sampled trees aged from 46 to 122 years (at $1.30 \mathrm{~m}$ in 1991) were bored at right angle to the slope direction so as to avoid tension wood. Any geometrical abnormalities of the trunk were avoided as well. Earlyand latewood transitions within the 7620 annual rings were defined according to qualitative aspects

Table II. Growth characteristics of 128 Corsican pine trees. $n=$ number of sampled trees per plot. Diameter was measured at breast height over bark. TR = Total ring; EW = Earlywood; LW = Latewood. The Mean Sensitivity (MS) is a measure of year-to-year variability and $\mathrm{AC}$ is the first-order autocorrelation coefficient of the ring widths. Both parameters were calculated on the unfiltered series of each tree and averaged per plot. Mean ring characteristics correspond to the period 1922-1991.

\begin{tabular}{|c|c|c|c|c|c|c|c|c|c|c|c|c|}
\hline \multirow[t]{2}{*}{$n$} & \multicolumn{3}{|c|}{$\begin{array}{l}\text { Age } \\
\text { (at } 1.30 \text { in 1991) }\end{array}$} & \multirow[t]{2}{*}{$\begin{array}{l}\text { Total Height } \\
\text { (in m) }\end{array}$} & \multirow[t]{2}{*}{$\begin{array}{l}\text { Diameter } \\
\text { (in } \mathrm{cm} \text { ) }\end{array}$} & \multirow{2}{*}{$\begin{array}{c}\text { Number } \\
\text { of } \\
\text { rings }\end{array}$} & \multicolumn{2}{|c|}{ TR } & \multicolumn{2}{|c|}{ EW } & \multicolumn{2}{|c|}{ LW } \\
\hline & mean & $\min$ & $\max$ & & & & MS & $\mathrm{AC}$ & MS & $\mathrm{AC}$ & MS & $\mathrm{AC}$ \\
\hline 10 & 53 & 49 & 54 & 21.5 & 53 & 500 & 0.27 & 0.68 & 0.28 & 0.64 & 0.39 & 0.56 \\
\hline 9 & 82 & 79 & 84 & 22.5 & 42 & 630 & 0.30 & 0.75 & 0.30 & 0.71 & 0.44 & 0.65 \\
\hline 10 & 117 & 115 & 119 & 28.0 & 51 & 700 & 0.30 & 0.66 & 0.32 & 0.60 & 0.39 & 0.56 \\
\hline 9 & 120 & 117 & 122 & 30.6 & 53 & 630 & 0.27 & 0.72 & 0.29 & 0.62 & 0.36 & 0.67 \\
\hline 10 & 91 & 90 & 91 & 34.8 & 50 & 700 & 0.33 & 0.52 & 0.33 & 0.50 & 0.45 & 0.40 \\
\hline 10 & 79 & 77 & 82 & 26.1 & 45 & 700 & 0.26 & 0.68 & 0.30 & 0.61 & 0.34 & 0.58 \\
\hline 10 & 51 & 46 & 54 & 20.9 & 35 & 482 & 0.23 & 0.65 & 0.26 & 0.67 & 0.32 & 0.49 \\
\hline 10 & 89 & 88 & 90 & 27.8 & 43 & 700 & 0.36 & 0.51 & 0.37 & 0.44 & 0.50 & 0.44 \\
\hline 10 & 53 & 49 & 56 & 25.4 & 45 & 511 & 0.24 & 0.55 & 0.27 & 0.55 & 0.39 & 0.40 \\
\hline 10 & 55 & 51 & 57 & 22.2 & 34 & 512 & 0.24 & 0.55 & 0.28 & 0.56 & 0.34 & 0.43 \\
\hline 10 & 55 & 53 & 57 & 20.0 & 34 & 537 & 0.35 & 0.71 & 0.35 & 0.74 & 0.53 & 0.28 \\
\hline 10 & 52 & 49 & 54 & 25.5 & 41 & 501 & 0.23 & 0.72 & 0.27 & 0.74 & 0.37 & 0.39 \\
\hline 10 & 53 & 52 & 54 & 22.2 & 37 & 517 & 0.25 & 0.81 & 0.27 & 0.80 & 0.39 & 0.52 \\
\hline 128 & 73 & & & 25.2 & 43.3 & 7620 & 0.28 & 0.65 & 0.30 & 0.63 & 0.40 & 0.49 \\
\hline
\end{tabular}


(darkening). To reduce bias in the tree-ring measurements (precision: $0.01 \mathrm{~mm}$ ), early- and latewood data were collected by one only person. Earlywood proportion ranged from 20 to $50 \%$ of total ring width according to cambial age [26]. The mean sensitivity (MS) and the first order-autocorrelation coefficient (AC) of the ring widths were calculated for each tree and averaged per plot over the range 1922-1991. MS is a measure of yearto-year variability and AC assesses the influence of the previous year's growth upon the current year's growth [10].

The individual ring-width series were crossdated after progressively detecting regional pointer years. When growing conditions are less favourable, the annual ring is narrower than normal and is commonly narrow for most trees falling under the influence of this environmental factor $[35,36]$. In our study, the pointer years were defined for each ring component as those calendar years when at least $75 \%$ of the 128 cross-dated trees presented the same sign of change (at least $10 \%$ narrower or wider than the previous year) [4].

The individual ring-width series were standardized by removing low- and intermediate-frequency variations, using the appropriate Auto-Regressive Moving-Average $(\operatorname{AR}(p)) M A(q))$ model $[17,19]$. A total of 31 different ARMA models were observed for the 128 single chronologies. The simple models $(1.0 ; 2.0$ and 3.0$)$ appeared for $70 \%$ of the trees. Total ring widths and earlywood widths were mainly standardized by the model (1.0) $(48 \%$ and $54 \%$ of the individual chronologies, respectively). The autocorrelation within the earlywood time-series was removed using a model (1.0) and (3.0) for $37 \%$ and $23 \%$ of the trees, respectively. In the final step, the selected model for each tree was determined by excluding complicated models that were difficult to explain from the biological point of view [29]. The dimensionless indices were averaged by year (58 to 128 rings per date; mean $=109$ ) to develop a master index chronology that represented the common high-frequency variation that existed in the 128 individual series. A master index chronology was calculated for each ring component separately.

For each ring component, the effect of climate on growth was investigated in three steps. First, pointer years were compared with climatic data. Second, simple correlation analyses were performed for the whole period 1922-1991 between monthly climatic data arranged as previously defined and the master index chronology. Third, bootstrapped response functions were calculated using the 24 monthly climatic parameters as regressors and the master index chronology as a dependent variable $[18,39]$. This method using bootstrap process consists in calculating the regression on years drawn by lots, some
50 simulations being involved in total. For each iteration, the regression coefficients and the multiple correlation of climatic regressors are computed on the years randomly selected (calibration years). An independent verification is done on the observations omitted from the subsample (verification years). At the end of the procedure, the response function consists of the mean values and standard deviation of partial regression and correlation coefficients (MRC and SC for calibration, MRV and SV for verification) between actual values and values reconstructed from climate. The significance of each bootstrapped regression coefficient is provided by the ratio between the mean value calculated from the results of these 50 simulations and its standard deviation. When the ratio ranges from $1.65-1.95,1.96-2.57,2.58-3.29$ and $>3.29$ the significance of the corresponding regression coefficients attains $90 \%, 95 \%, 99 \%, 99.9 \%$ of probability respectively [39]. The global significance of the response function is defined by the ratio between MRV and SV according to the same probability levels.

\section{RESULTS}

\subsection{Mean sensitivity and autocorrelation}

The mean sensitivity for the total ring width ranged from 0.23 to 0.36 with an average value of 0.28 (table II). These values were higher for latewood $(0.32$ to 0.53 ; mean $=0.40)$ than for earlywood $(0.26$ to 0.36 ; mean $=0.30)$. These data indicated appreciable interannual variations in the ring width series and may suggest that latewood was more sensitive to climate than earlywood. First order-autocorrelation coefficients (AC) averaged $0.64,0.67$ and 0.46 for total ring, earlywood and latewood, respectively. For earlywood, this high coefficient indicated a strong dependence of current growth on the previous year's growth. Because of its lower autocorrelation, latewood seemed to be the least deterministic part of the ring.

\subsection{Variations in climatic data}

A linear increasing trend was observed in minimum temperature $\left(T_{\mathrm{n}}\right)$ during the period 1950-1997 with a slope of $0.032{ }^{\circ} \mathrm{C}$. year ${ }^{-1}$ and $0.039{ }^{\circ} \mathrm{C}$. year $^{-1}$ for the total year and the growing season, respectively ( $r=0.64$ for both periods; $p<0.001$ ) (figure 2). The positive trend was observed for each month from May to October (excepted September), but was more pronounced for July $\left(0.04^{\circ} \mathrm{C}\right.$. year $\left.{ }^{-1}\right)$ and August $\left(0.054^{\circ} \mathrm{C}\right.$. year $\left.{ }^{-1}\right)(r=0.48$ and $0.59, p<0.001)$. During the same period, the increase in maximum temperature $\left(T_{\mathrm{x}}\right)$ was less pronounced and only significant for August $\left(0.058^{\circ} \mathrm{C}\right.$. 
(a)

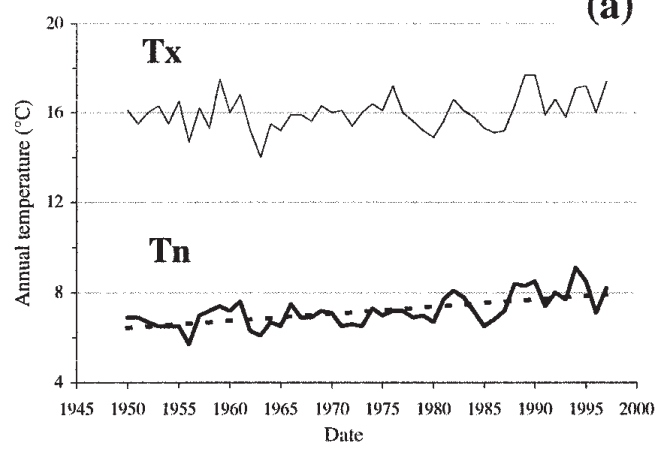

(b)

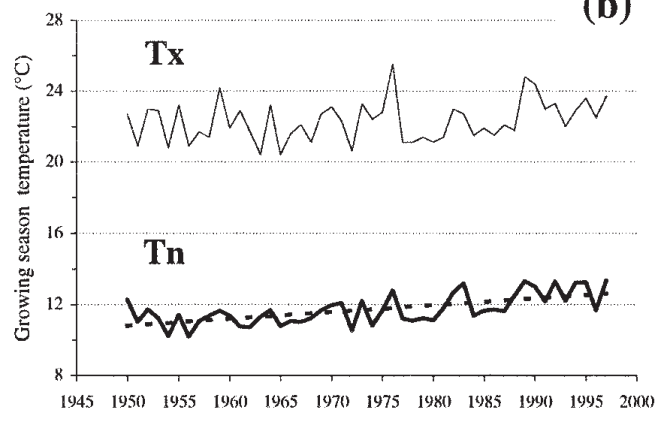

Date

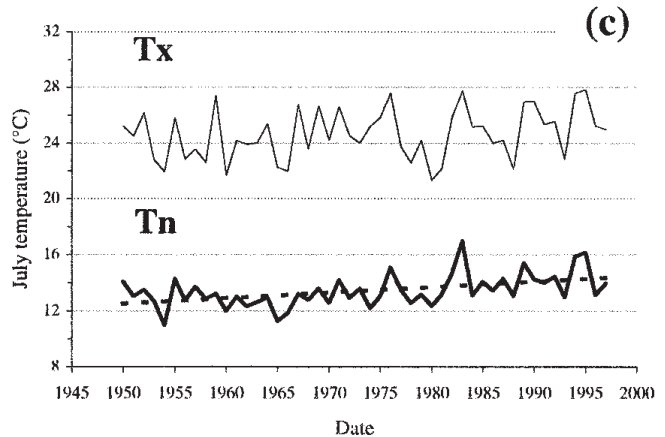

Figure 2. Inter-annual variations (solid line) of annual (a), growing season (b) and July (c) minimal $\left(T_{\mathrm{n}}\right)$ and maximal $\left(T_{\mathrm{x}}\right)$ temperatures in Angers (period 1950-1997). The dashed lines indicate significant linear trends at the $95 \%$ level.

year $\left.^{-1}, r=0.41, p<0.01\right)$. Consequently, the mean temperature significantly increased in July $\left(0.036^{\circ} \mathrm{C}\right.$. year ${ }^{-1}$, $r=0.36, p<0.01)$ and August $\left(0.057{ }^{\circ} \mathrm{C}\right.$. year ${ }^{-1}, r=$ $0.51, p<0.001)$ and for the total year $\left(0.024^{\circ} \mathrm{C}\right.$. year $^{-1}, r$ $=0.48, p<0.001)$ and the growing season $\left(0.027^{\circ} \mathrm{C}\right.$. year $\left.{ }^{-1}, r=0.43, p<0.001\right)$. On the contrary, thermal amplitudes and precipitation did not show significant lin- ear trends. The recent years (1990-1997) appeared to be the warmest of the whole period (table III). The mean annual temperature ranged from 11.6 to $13.1{ }^{\circ} \mathrm{C}$ (mean $=12.4^{\circ} \mathrm{C}$ ) with a mean summer temperature (July and August) above normal $\left(18.4\right.$ to $22^{\circ} \mathrm{C}$; mean $=20.5^{\circ} \mathrm{C}$; normal $\left.=18.8^{\circ} \mathrm{C}\right)$.

\subsection{Pointer years and extreme climatic factors}

There were many points of agreement between extreme low-growth years and summer drought (low and high values of precipitation and temperature during the growing season) (table IV). For the period 1948-1991, 9 years were characterized by growing season rainfall deficits above $40 \mathrm{~mm}$ (42 to $128 \mathrm{~mm}$ : mean deficit $=$ $82 \mathrm{~mm}$ ). Among these dry years, 6 corresponded to negative pointer years $(1949,1959,1962,1976,1989$, 1990). The years 1959, 1962, 1976 and 1990 were also characterized by an annual rainfall deficit above 140 $\mathrm{mm}$. Of the 15 pointer years, only the negative year 1976 occurred in both ring components. The importance of this year could be explained by the exceptional duration of the drought that began at the end of the 1975 and lasted until the late summer of 1976 . The significant decrease observed in 1986 cannot be associated to a rainfall deficit but seemed to be linked to the extreme frost in February (mean temperature $=-1.2{ }^{\circ} \mathrm{C}$ ). For the widegrowth years, three of the five positive years coincided with rainy years and wet and cool summer (table IV). For the positive years 1977 and 1985, no obvious correlation appeared between wide-growth and available climatic parameters suggesting the effects of different ecological events or statistical artefacts. The frequency of pointer years was significantly higher for latewood than for earlywood $\left(27 \%\right.$ and $7 \%$ respectively; $\chi^{2}=5.1$, $p<0.05)$. Most of the pointer years defined for the total ring corresponded to those of the latewood component.

\subsection{Simple growth-climate correlations}

Total ring growth was positively correlated with prior October and current January, June and July precipitation (figure 3). Significant negative relationships were shown between total ring indices and temperature during May, July and August. The highest correlation coefficient was found for July temperature.

Only temperature (May and July) negatively influenced earlywood formation (figure 3). May temperature had the highest correlation with earlywood.

Both precipitation (positively) and temperature (negatively) influenced latewood formation. For precipitation, 
significant months were prior October and current January, June, July and August. Latewood growth was negatively influenced only by summer temperature (figure 3).

The common significant correlation coefficients suggested that the major climatic signal in Corsican pine tree rings was linked to summer drought.

\subsection{Response function analysis}

For the calibration years, the MRC (SC) were 0.83 (0.04), $0.80(0.04)$ and $0.82(0.04)$ for total ring, earlywood and latewood, respectively. The corresponding verification coefficients (MRV and SV) were 0.46 (0.12), $0.37(0.16)$ and $0.42(0.12)$ (figure 3). These high verification values demonstrated the reliability of the regression estimate. Total ring and latewood response functions were significant at the threshold $99.9 \%$. Earlywood response function was significant at the threshold $95 \%$.

Climatic models found seven months to be significant and each chronology was more closely correlated to temperature than precipitation. Only prior October precipitation and current July temperature entered in all models with positive and negative regression coefficients, respectively. Earlywood and total ring growth showed a highly significant negative association with current May temperature. Previous October and current July temperature also negatively influenced earlywood growth whereas January temperature and previous October precipitation had a positive effect. The regression coefficients suggested that earlywood formation was enhanced by warm and wet conditions during autumn and winter and was reduced by warm spring. For the latewood component, the significant regression coefficients suggested that growth was enhanced by wet conditions during prior October and current February and June but was highly reduced by warm summer. The positive effect of February and June precipitation was also significant for the total ring growth.

\section{DISCUSSION AND CONCLUSION}

The calculation of response functions provides readily accessible information about the dominant mode of linear response between tree-ring and climate variables of many years. As a disadvantage, however, response functions and also correlation analysis are unable to render evidence about less frequent and time-dependent growth limiting factors. The pointer years analysis provides information on an individual year basis and can be considered as a supplement to the calculation of linear regression models. The combination of these different procedures gives the most comprehensive dendroclimatological information [24]. In this study, the three methods clearly showed that the radial growth of mature Corsican pine trees, growing at low elevation on acidic well-drained soils in western France, is mainly limited by summer drought (deficient water balance as a result of low precipitation and high temperature). Extreme growth reductions are more frequent than positive pointer years and specially highlight the effects of low precipitation. This may be due to the fact that during strongly adverse conditions, the tree response is more uniform, even within a large geographic region, whereas in favourable conditions this response may be more heterogeneous [31]. Because response functions give information between tree-ring and climate of many years, our results suggest that temperature is more important than precipitation in the studied area. This strong negative correlation between summer temperature and growth is similar to the results reported for Pinus sylvestris [6, 12, 32], Pinus taeda [13], Pinus uncinata [32, 34] and is consistent with findings obtained for old naturally Pinus

Table III. Variations of minimum $\left(T_{\mathrm{n}}\right)$, maximum $\left(T_{\mathrm{x}}\right)$, mean temperatures $\left(T_{\mathrm{m}}\right)$, thermal amplitude $\left(T_{\mathrm{x}}-T_{\mathrm{n}}\right)$ and precipitation $(P)$ at decadal scale for the year and the growing season (GS; May to September). Means with the same letter are not significantly different at the 0.05 level (Bonferroni (Dunn) $\mathrm{T}$ tests; Critical value for $T=3.25 ; D F=47$ ).

\begin{tabular}{|c|c|c|c|c|c|c|c|c|c|c|c|c|c|c|c|c|c|c|c|c|}
\hline \multirow{3}{*}{$\begin{array}{l}\text { Period } \\
1950-1959\end{array}$} & \multirow{2}{*}{\multicolumn{4}{|c|}{$T_{\mathrm{n}}\left({ }^{\circ} \mathrm{C}\right)$}} & \multicolumn{4}{|c|}{$T_{x}\left({ }^{\circ} \mathrm{C}\right)$} & \multicolumn{4}{|c|}{$T_{\mathrm{m}}\left({ }^{\circ} \mathrm{C}\right)$} & \multicolumn{4}{|c|}{$\left(T_{\mathrm{x}}-T_{\mathrm{v}}\right)\left({ }^{\circ} \mathrm{C}\right)$} & \multicolumn{4}{|c|}{$P(\mathrm{~mm})$} \\
\hline & & & & & \multicolumn{2}{|c|}{ Year } & \multicolumn{2}{|c|}{ GS } & \multicolumn{2}{|c|}{ Year $^{m}$} & \multicolumn{2}{|c|}{ GS } & \multicolumn{2}{|c|}{ Year } & \multicolumn{2}{|c|}{ GS } & \multicolumn{2}{|c|}{ Year } & \multicolumn{2}{|c|}{ GS } \\
\hline & 6.7 & $\mathrm{bc}$ & 11.2 & $\mathrm{~cd}$ & 16.0 & $\mathrm{a}$ & 22.2 & $\mathrm{a}$ & 11.4 & b & 16.7 & $a b$ & 9.2 & $\mathrm{a}$ & 11.0 & $\mathrm{a}$ & 598 & a & 245 & $\mathrm{a}$ \\
\hline $1960-1969$ & 6.9 & $\mathrm{bc}$ & 11.1 & $\mathrm{~d}$ & 15.6 & $\mathrm{a}$ & 21.8 & $\mathrm{a}$ & 11.3 & b & 16.5 & $\mathrm{~b}$ & 8.8 & $a b c$ & 10.7 & $\mathrm{a}$ & 608 & $\mathrm{a}$ & 216 & $\mathrm{a}$ \\
\hline $1970-1979$ & 6.9 & $\mathrm{bc}$ & 11.5 & bcd & 16.0 & $\mathrm{a}$ & 22.4 & a & 11.5 & $\mathrm{~b}$ & 16.9 & $a b$ & 9.1 & $a b$ & 10.8 & $\mathrm{a}$ & 590 & $\mathrm{a}$ & 224 & $\mathrm{a}$ \\
\hline 1980-1989 & 7.5 & $a b c$ & 12.1 & $a b c$ & 15.9 & $\mathrm{a}$ & 22.2 & $\mathrm{a}$ & 11.7 & $a b$ & 17.1 & $a b$ & 8.4 & $a b c$ & 10.1 & $\mathrm{a}$ & 685 & $\mathrm{a}$ & 248 & $\mathrm{a}$ \\
\hline $1990-1997$ & 8.1 & $\mathrm{a}$ & 12.8 & $\mathrm{a}$ & 16.7 & a & 23.2 & a & 12.4 & $\mathrm{a}$ & 17.8 & a & 8.7 & $a b c$ & 10.4 & $\mathrm{a}$ & 655 & a & 242 & a \\
\hline
\end{tabular}



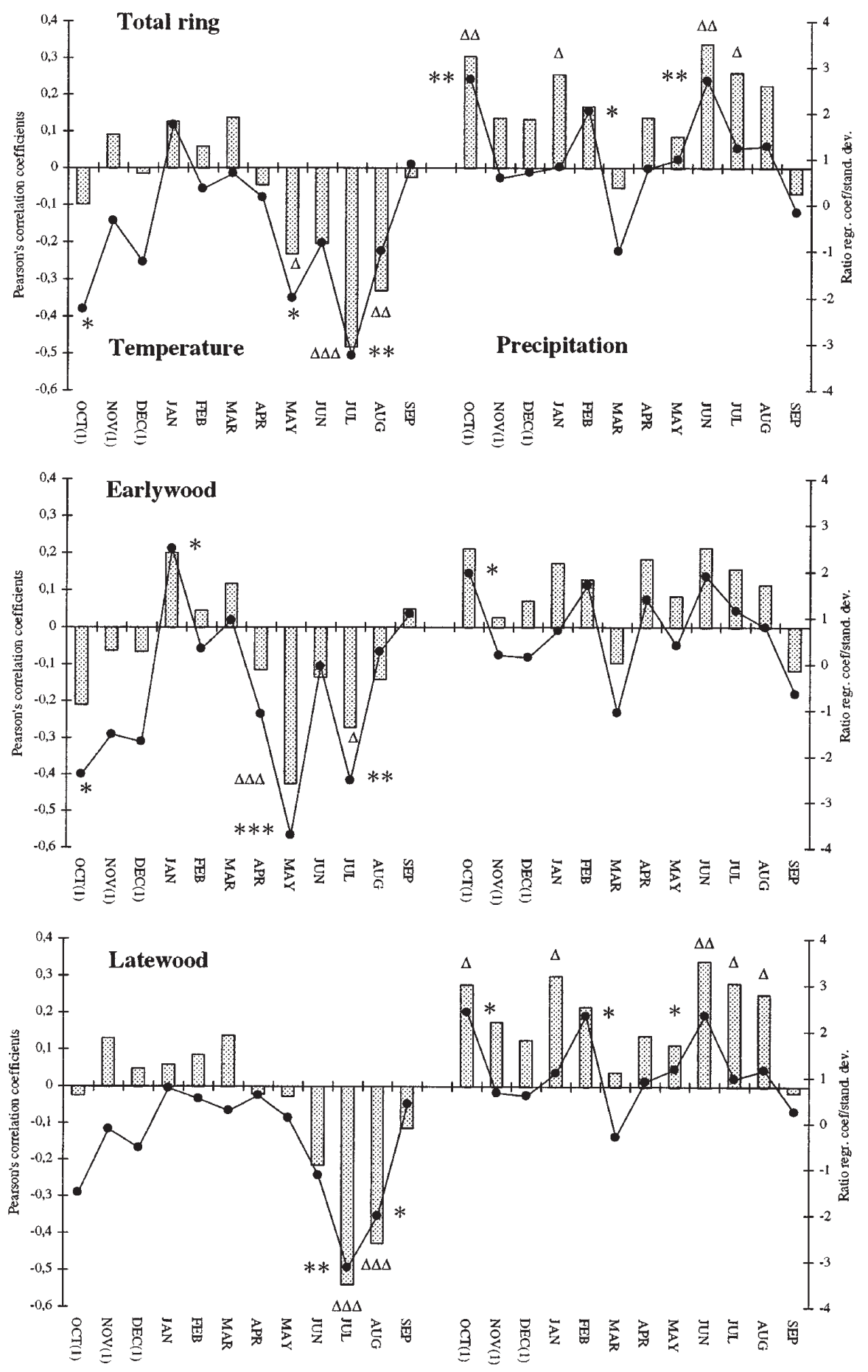

Figure 3. Simple Pearson's correlation ( $r$ ) coefficients (bars) and response function coefficients (lines) for monthly temperature and precipitation from previous October to current September for each ring compartment (period 1922-1991;n=70). The number of stars (for response function) and triangles (for correlation function) indicate significance at the 95\%, 99\% and 99.9\% levels. 
Table IV. Calendar years characterized by a strong relative increase or decrease in radial growth for each ring compartment. TR $=$ total ring; EW = Earlywood; LW = Latewood. The years refer to a strong relative increase or decrease found in at least $75 \%$ of the 128 crossdated trees (period 1948-1991). The number in brackets correspond to the mean of the parameter calculated over the period 1961-1990. Growing season (GS) = May to September. Summer = July and August.

\begin{tabular}{|c|c|c|c|c|c|c|}
\hline \multirow{2}{*}{$\begin{array}{l}\text { Negative } \\
\text { pointer years }\end{array}$} & \multicolumn{3}{|c|}{ Relative decrease (\%) } & \multicolumn{2}{|c|}{ Deviation from the mean (in mm) } & \multirow{2}{*}{$\begin{array}{l}\text { Deviation from } \\
\text { mean Summer temp. }\left(18.8^{\circ} \mathrm{C}\right)\end{array}$} \\
\hline & $\mathrm{TR}$ & EW & LW & Year (618) & GS (224) & \\
\hline 1949 & & & -34 & -116 & -46 & 2.1 \\
\hline 1952 & -31 & -30 & & 202 & 48 & 0.7 \\
\hline 1955 & & & -38 & -79 & -12 & 1.5 \\
\hline 1959 & -30 & & -45 & -155 & -117 & 1.1 \\
\hline 1962 & -23 & & -32 & -147 & -86 & -0.4 \\
\hline 1969 & -24 & & & -75 & -32 & 1.0 \\
\hline 1976 & -44 & -35 & -54 & -146 & -63 & 2.4 \\
\hline 1986 & -29 & & -41 & 68 & -16 & -0.9 \\
\hline 1989 & -39 & & -60 & -27 & -101 & 1.9 \\
\hline 1990 & -25 & -26 & & -157 & -128 & 2.5 \\
\hline \multirow{2}{*}{$\begin{array}{l}\text { Positive } \\
\text { pointer years }\end{array}$} & \multicolumn{3}{|c|}{ Relative increase (\%) } & \multicolumn{2}{|c|}{ Deviation from the mean (in $\mathrm{mm}$ ) } & Deviation from \\
\hline & $\mathrm{TR}$ & EW & LW & Year (618) & GS (224) & mean Summer temp. $\left(18.8^{\circ} \mathrm{C}\right)$ \\
\hline 1950 & & & 86 & 165 & 125 & 0.1 \\
\hline 1977 & 69 & & 197 & -14 & -19 & -0.8 \\
\hline 1980 & & & 94 & 107 & 66 & -1.0 \\
\hline 1985 & & & 50 & -67 & -25 & -0.3 \\
\hline 1988 & 73 & & 145 & 87 & -12 & -0.6 \\
\hline
\end{tabular}

nigra stands from central mountains of Spain [9] and young trees $[20,21]$. Physiological studies have found that the net assimilation rate of Pinus nigra sharply decreased when soil dried as a result of an efficient and rapid stomatal control of transpirational water loss (decreasing photosynthate production and carbohydrate storage) $[1,27]$. Thus, for the Western France, Corsican pine confirmed to be as a drought-sensitive species.

Latewood appeared to be more sensitive to climate variations than earlywood and the response function obtained from latewood was very similar to the one defined from total ring series. The reliability of the climatic response of early- and latewood widths suggests that in future studies both parameters can be used to obtain subseasonal climatic information.

The exact date of transition from early- to latewood was not investigated in the present study. Nevertheless, response functions suggested that the period of earlywood formation occurred mainly in early spring (strong negative effect of May temperature) whereas the growth of the latewood band was maximum in mid-summer (strong negative effect of July temperature). Warm May temperatures could reduce earlywood width by creating water stress conditions at the beginning of the growing season [40]. These results are consistent with intra-annu- al anatomical observations of Pinus unicnata and Pinus sylvestris in the central spanish Pyrenees [7].

Because most trees growing in the temperate zone require high temperature in late winter for the use of reserves at the beginning of the vegetation period [37], a warm winter may influence the breaking of dormancy and the resumption of physiological activity in the tree and thus increase the duration of the current growing season. High temperature may also enhance winter photosynthesis, which is known to play an important role in some coniferous species $[14,16]$. The effect of prior October climate conditions may indicate some preconditioning of current year's growth by climate during the previous year. In many conifer species, carbohydrate reserves are built up in autumn and stored during the winter until growth starts. Thus, it may be suggested that Corsican pine is not able to fix significant amounts of carbon during warm, dry October weather conditions, which may cause a reduction in growth the following year by reducing carbohydrate reserves [15].

The trends in local climate are consistent with others observations in France [8, 33], Austria [22] and, in a more general context, with the important change in climate observed over Northern Hemisphere land areas since the mid-19th century [30]. In this general context of climatic changes, the highly significant inverse 
correlation between inter-annual Corsican pine ring variations and summer temperature dismiss the hypothesis that warm summer could induce growth enhancement in the next years. On the contrary, using the linear relationships observed over the range of mean monthly July temperature $\left(16.4\right.$ to $22.4^{\circ} \mathrm{C}$ ), a mean increase from 1 to $3^{\circ} \mathrm{C}$ is likely to decrease total ring growth by 3 to 11 per cent over present day values. Thus, although forest growth simulation models based on different scenarios of climate change are still unclear, a steady regional warming may have a major effect on the pine environment and may endanger the establishment and the survival of the Corsican pine plantations in western France.

Acknowledgements: The author is grateful to the French National Forest Office, to the Regional Forestry Administrations of Nantes and Orléans, and to several forest owners who provided financial resources for this project. The author also expresses his gratitude to Richard Chevalier, Yann Dumas, François Gérémia, Jean-Michel Gilbert, Christian Kieffer, Roger Schipfer and Bernadette Vallée for their helpful technical assistance and J. Guiot in different statistical aspects of the field work.

\section{REFERENCES}

[1] Aussenac G., Comportement hydrique de rameaux excisés de quelques espèces de sapins et de pins noirs en phase de dessication, Ann. Sci. For. 37 (1980) 201-215.

[2] Becker M., The role of climate on present and past vitality of silver fir forests in the Vosges mountains of northeastern France, Can. J. For. Res. 19 (1989) 1110-1117.

[3] Becker M., Bert G.D., Landmann G., Levy G., Rameau J.C., Ulrich E., Growth and decline symptoms of Silver Fir and Norway Spruce in Northeastern France: Relation to climate, nutrition and silviculture, in: Landmann G. and Bonneau M. (Eds.), Forest decline and atmospheric deposition effects in the French mountains, Springer, Berlin Heidelberg New York, 1995, pp. 120-142.

[4] Becker M., Nieminen T.M., Gérémia F., Short-term variations and long-term changes in oak productivity in northeastern France, The role of climate and atmospheric $\mathrm{CO}^{2}$, Ann. Sci. For. 51 (1994) 477-492.

[5] Beniston M., Innes J.L., The Impacts of Climatic Variability on Forests, Springer-Verlag, Berlin, 1998, p. 329.

[6] Briffa K.R., Jones P.D., Pilcher J.R., Hughes M.K., Reconstructing summer temperatures in northern Fennoscandinavia back to A.D. 1700 using tree-ring data from Scots pine, Artic Alpine Res. 20 (1988) 385-394.

[7] Camarero J.J., Guerrero J., Gutiérrez C., Gutiérrez E., Tree-ring growth and structure of Pinus uncinata and Pinus sylvestris in the central spanish Pyrenees, Artic Alpine Res. 30 (1988) $1-10$.
[8] Dessens J., Severe consecutive weather in the context of a nighttime global warming, Geophys. Res. Lett. 22 (1995) 1241-1244.

[9] Fernandez A., Génova M., Creus J., Gutiérrez E., Dendroclimatological investigation covering the last 300 years in central Spain, in: Dean J.S., Meko D.M., and Swetnam T.W. (Eds.), Tree Rings, Environment and Humanity, Radiocarbon. (1996) 181-190.

[10] Fritts H.C., Tree-ring and climate, Academic Press London, 1976, p. 576.

[11] Fritts H.C., Xiangding W., A comparison between response-function analysis and other regression techniques, Tree-ring Bull. 46 (1986) 31-46.

[12] Graces J., Norton D.A., Climate and growth of Pinus sylvestris at its upper altitudinal limit in Scotland: evidence from tree growth-rings, J. Ecol. 78 (1990) 601-610.

[13] Gregg B.M., Dougherty P.M., Hennessey T.C., Growth and wood quality of young loblolly pine trees in relation to stand density and climatic factors, Can. J. For. Res. 18 (1988) 851-858.

[14] Guehl J.M., Étude comparée des potentialités hivernales d'assimilation carbonée de trois conifères de la zone tempérée (Pseudotsuga menziesii Mirb., Abies alba Mill. et Picea excelsa Link.), Ann. Sci. For. 42 (1985) 23-38.

[15] Guehl J.M., Clement A., Kaushal P., Aussenac G., Planting stress, water status and non-structural carbohydrate concentrations in Corsican pine seedlings, Tree Physiol. 12 (1993) 173-183.

[16] Guehl J.M., De Vitry C., Aussenac G., Photosynthèse hivernale du douglas vert (Pseudotsuga menziesii Mirb Franco) et du cèdre (Cedrus atlantica Manetti et Cedrus libani Loud). Essai de modélisation à l'échelle du rameau, Acta Ecol. Ecol. Plant. 6 (1985) 125-146.

[17] Guiot J., ARMA techniques for modelling Tree-ring response to climate and for reconstructing variations of paleoclimates, Ecol. Model. 33 (1986) 149-171.

[18] Guiot J., The bootstrapped response function, TreeRing Bull. 51 (1991) 39-41.

[19] Guiot J., Tessier L., Serre-Bachet F., Application de la modélisation ARMA en dendroclimatologie, C. R. Acad. Sc. Paris 294 (1982) 133-136.

[20] Guyon J.P., Influence du climat sur l'expression des composantes de la croissance en hauteur chez le Pin noir d'Autriche (Pinus nigra Arn. ssp. nigricans), Ann. Sci. For. 43 (1986) 207-226.

[21] Guyon J.P., Betored D., Kremer A., Influence de la température et des précipitations sur l'activité méristématique apicale dans une régénération naturelle de pin noir d'Autriche (Pinus nigra Arn. ssp. nigricans Host), Acta Ecol. Ecol. Plant. 8, 22 (1987) 309-320.

[22] Hasenauer H., Nemani R.R., Schadauer K., Running S.W., Forest growth response to changing climate between 1961 and 1990 in Austria, For. Ecol. Manage. 122 (1999) 209219. 
[23] Jordan D.N., Lockaby B.G., Time series modelling of relationships between climate and long term radial growth of loblolly pine, Can. J. For. Res. 20 (1990) 738-742.

[24] Kienast F., Schweingruber FH., Bräker OU., Schär E., Tree-ring studies on conifers along ecological gradients and the potential of single-year analyses, Can. J. For. Res. 17 (1987) 683-696.

[25] Landmann G., Role of climate Stand Dynamics and Past Managment in Forest Declines: A Review of Ten Years of Field Ecology in France, in: Huettl, Mueller, Dombois (Eds.), Forest Decline in the Atlantic and Pacific Region, 1993, pp. 19-39.

[26] Lebourgeois F., Becker M., Dendroécologie du pin laricio de Corse dans l'Ouest de la France. Evolution du potentiel de croissance au cours des dernières décennies, Ann. Sci. For. 53 (1996) 931-946.

[27] Lebourgeois F., Lévy G., Aussenac G., Clerc B., Willm F., Influence of soil drying on leaf water potential, photosynthesis, stomatal conductance and growth in two black pine varieties, Ann. Sci. For. 55 (1998) 287-299.

[28] Lebourgeois F., Lévy G., Becker M., Lefèvre Y., Rôle de la nutrition minérale et de l'approvisionnement en eau sur la croissance du pin laricio de Corse dans l'ouest de la France, Ann. Sci. For. 54 (1997) 279-300.

[29] Malgras J., Debouzie D., Les modèles ARMA peuventils être utilisés avec confiance en écologie ? Acta Oecol. 18 (1997) 427-447.

[30] Mann M.E., Bradley R.S., Hughes M.K., Global-scale temperature patterns and climate forcing over the past six centuries, Nature 392 (1998) 779-787

[31] Motta R., Nola P., Drendrochrono-ecological signal in three stone pine (Pinus cembra L.) chronologies from the western Italian Alps, Dendrochronologia 14 (1996) 43-57.
[32] Richter K., Eckstein D., Holmes R.L., The dendrochronological signal of pine trees (Pinus ssp.) in Spain, Tree-Ring Bulletin 51 (1991) 1-13.

[33] Rolland C., Petitcolas V., and Michalet R., Changes in radial tree growth for Picea abies, Larix decidua, Pinus cembra and Pinus uncinata near the alpine timberline since 1750, Trees 13 (1998) 40-53.

[34] Rolland C., Schueller J.F., Relationships between mountain pine and climate in the french Pyrenees (FontRomeu) studied using the radiodensitometrical method, Pirineos 143-144 (1994) 55-70.

[35] Schweingruber F. H., Abrupt growth changes in conifers, IAWA Bul. 7 (1986) 277-283.

[36] Schweingruber F.H., Albrecht H., Beck M., Hessel J., Joos K., Keller D., Kontic R., Lange K., Niederer M., Nippel C., Spang S., Spinnler A., Steiner B., Winlkler-Seifert A., Abrupte Zuwachsschwankungen in jahrringabfolgen als ökologische indikatoren, Dendrochronologia 4 (1986) 125-184.

[37] Serre F., Les rapports de la croissance et du climat chez le Pin d'Alep (Pinus halepensis Mill.). I. Méthodes utilisées. L'activité cambiale et le climat, Ecol. Plant. 11 (1976) 143171.

[38] Tessier L., Spatio-temporal analysis of climate-tree ring relationships, New Phytol. 111 (1986) 517-529.

[39] Tessier L., Nola P., Serre-Bachet F., Deciduous Quercus in the Mediterranean region: tree-ring/climate relationships, New Phytol. 126 (1994) 355-367.

[40] Zahner R., Lotan J.E., Baughman W.D., EarlywoodLatewood features of Red Pine grown under simulated drought and irrigation, For. Sci. 10 (1964) 361-370. 